\title{
The Binary Conception of Economics, Janus-Faced Development and the Aspiration for Accelerated and Shared Growth in South Africa
}

\author{
Johannes Tsheola \\ University of Limpopo, Limpopo Province, South Africa
}

\begin{abstract}
Neoliberal macroeconomics delivered positive economic growth for most developing economies, amidst persistent deprivation and inequalities, and rigged market capitalism wherein the state incrementally substitutes itself for society, paradoxically creating bloated welfare rather than people participation, empowerment and human development. South Africa's pursuit of Growth, Employment and Redistribution (GEAR) produced positive economic growth devoid of human development. Inevitably, government adopted Accelerated and Shared Growth Initiative for South Africa (AsgiSA) in 2006 with the intention of engendering "shared” growth for all. This article argues that the occurrence of Janus-faced development in South Africa reflects the failure of micro-scale people empowerment that is precipitated by the exclusion of poor people's "asset base" from treatment as productive and investment capital within the hegemonic GEAR macroeconomics. It concludes that AsgiSA would fail to engender "shared" growth because it does not provide for the (re)capitalisation of the bottom half of society as its primary transformative agenda.
\end{abstract}

Keywords: economics, growth-orientation, people-centeredness, GEAR, AsgiSA, South Africa

\section{Introduction}

Analyzing post-apartheid development, Nabudere (2006, p. 33) declared that developmentalism is "dead but not yet buried because theory has not matched reality”. Western self-conceptions universalised under neo-libertarian globalisation, failed to replicate their successes in developing economies (Amin, 2001; Bayart, 2000; Cheru, 2002; Nabudere, 2006; Tsheola, 2002a, 2002b, 2003). With the ascendancy of "there is no alternative” (TINA) paralysis, countries that could have ordinarily exercised alternative policy choices were forced to adhere to the Washington Consensus. Independent sub-Saharan African states adopted structural adjustments (SAPs), underwritten by neo-libertarian macroeconomics and capital accumulation philosophies, producing a litany of incomplete skeletons of misconceived economics and development practice. Post-apartheid South Africa's macroeconomics too became replicas of Western conceptions of selfhood (Nabudere, 2006;

\footnotetext{
Johannes Tsheola, Ph.D. in Geography, Senior Lecturer, Department of Development Planning and Management, University of Limpopo.

Correspondence concerning this article should be addressed to Johannes Tsheola, P.O. Box 313, Fauna Park 0787, South Africa E-mail: Johannes.tsheola@ul.ac.za.
} 
Tsheola, 2003).

For former colonial economies, neoliberal macroeconomics perpetuated import-dependent production structures and vertical external relations of trade with former colonial powers (Cheru, 2002; Tsheola, 2002c, 2003). Notwithstanding the wealth generation opportunities associated with the ascendency of globalisation, "Africa continues to project a sad case of a region that is more or less excluded from world trade and its benefits" (Ilorah, 2008, p. 96). The ongoing inflexible binary conceptions of economics are central to the development conundrum experienced by developing economies. Cement Sunter blames South Africa's development puzzle on "the triumph of Thatcherism and the Washington Consensus and the international rejection of Keynesian Theory" (as cited in Legum, 2002, p. iv). This article adopts Cassim's (2006, p. 55) argument that "the ultimate test of reform is the impact it has on the poorest segments of society”, and argues that post-apartheid South Africa's policy choices delivered Janus-faced development of persistent poverty and inequality amidst positive and increasing economic growth because the transformative agenda did not (re)capitalise the bottom half of the society for participation in the economics of capital accumulation.

The legacies of colonialism and apartheid entailed broadly participatory and inclusive post-1994 development policy (Cloete, 2006). Government adopted a mix of economic growth and people-centred approaches to development in the Reconstruction and Development Programme (RDP) (Cloete, 2006; Davids, 2005; de Coning, 2006; Munslow \& FitzGerald, 1997; Munslow, Fitzgerald, \& McLennan, 1997; Padayachee, 2006; Tsheola, 2002a, 2003). The RDP vision attempted to strike a balance between growth-orientation, people-centeredness and environmental sustainability (Cloete, 2006; Tsheola, 2002a, 2003). The ascendency of GEAR macroeconomics engendered a bias towards macro-policies underpinned by quantitative-development and growth-orientation, entrenching the foundational neoliberal principle that economic growth is a function of asset accumulation and treatment thereof as productive and investment capital.

This article teases out three foundational norms of the hegemonic neo-libertarian macroeconomics and their linkages to positive economic growth, devoid of micro-scale empowerment and human development. It demonstrates that the post-apartheid Janus-faced development experience is associated with the circumvention of the "asset base" managed by poor people, whose majority the state sought to cater for through social welfare. By 2007, over 12 million South Africans (about 26\% of the total population) received social grants whilst annual economic growth rate was about 5\% (RSA, 2007). Apparently, GEAR's transformative agenda failed to (re)capitalise the bottom half of the population for participation in the hegemonic economics of capital accumulation. AsgiSA also does not provide for the recognition and treatment of poor people's assets as capital.

The next section discusses the binary nature of conceptions of economics in order to consolidate the conceptual argument that neoliberal macro-policies are associated with Janus-faced development for erstwhile colonies in sub-Saharan Africa. Section three analyses GEAR's delusional presumption of wealth generation, job creation and trickle-down economics, and section four proposes that the Janus-faced development puzzle cannot be divorced from GEAR macroeconomics' exclusion of the assets of the poor from the hegemonic process of capital accumulation. Section five argues that "sharing in economic growth" is not necessarily congruent with engendering authentic people's participation and empowerment for the poor. The article concludes that rather than hoping for trickle-down economics, South Africa's transformative agenda needs to focus on (re)capitalisation of the bottom half of the society for participation in the process of capital accumulation. 


\section{Binary Conceptions of Economics}

Conceptions of economics are highly contested and controversial, largely because of the "vested interests in how change and development are to proceed” (Desai \& Potter, 2002, p. 59). The Washington Consensus conceives economics as "the logic of a system", and its critics argue that economics is "about people and how they are being served by whatever system" adopted (Legum, 2002, p. 1). Conceptions of economics as "the logic of a system" are linked to comparative advantage theory, which emphasises the role of free global trade in economic growth (Cheru, 2002; Desai \& Potter, 2002; Ilorah, 2008; Todaro, 1997). The free global trade argument holds that "the only economic system that works is one in which all people on the planet must compete with all others to produce and sell goods and services” (Legum, 2002, p. 2). Global trade is presumed to promote "competition, investments, knowledge transfer and growth" and foreign exchange from exports, to finance imports (Ilorah, 2008, p. 83). Countries are expected to engage global trade according to their comparative advantages and to enhanced self-sufficiency, wealth and growth (Legum, 2002; Ilorah, 2008; Todaro, 1997). Domestically, poor people would presumably benefit through trickle-down of jobs and income from fast growing national economies (Cheru, 2002; Ilorah, 2008; Legum, 2002; Todaro, 1997). The conceptual heritage of the "new-left orthodoxy", neoliberal macro-policies, structural adjustments and the populist poverty alleviation strategies is now exulted as neoclassical approaches (Adedeji, 2009; Cheru, 2002; Dlamini-Zuma, 2009; Ilorah, 2008; Tsheola, 2002c), describing a plethora of dualistic and linear conceptions of development in “modernisation theory, unbalanced and unequal growth, and top-down and hierarchical formulations” (Desai \& Potter, 2002, p. 59).

Ascendancy of neoclassical approaches truncated discussions of alternative development paths through the TINA paralysis (Desai \& Potter, 2002; Ilorah 2008; Legum, 2002; Tsheola, 2002b). Whereas political economists conceived economics as "a branch of moral science" and "part of an ethical system in the service of humanity", the TINA paralysis entrenched "immutable laws" and overtook politics "in deciding how people should live” (Legum, 2002, pp. 1-2). Increasingly, a picture of humanity being helpless was crafted, especially for developing economies, analogous to "the sinking ship" imagery. Simultaneously, Keynes' alternative conception of economics as "value-laden” and "a servant of humanity's development” was undermined (Cheru, 2002; Dlamini-Zuma, 2009; Ilorah, 2008; Legum, 2002; Todaro, 1997). Keynes demonstrated that a stable macroeconomic framework for production, wherein state decisions could be made about the fairer distribution of wealth, was possible (Adedeji, 2009; Cheru, 2002; Dlamini-Zuma, 2009; Ilorah, 2008; Todaro, 1997). Markets are, by their nature, imperfect and unable to be self-correcting. Therefore, state regulation and participation in the economy are necessary. Keynes' economics involve the pursuit of political justice and gratification of the electorate's interests (Legum, 2002). The recent global market crisis showed that developed economies, in consort with Keynes' economics, adopted measures that they previously "shunned”, paradoxically unravelling "some fundamental fault lines of (neoliberal) globalisation” (Dlamini-Zuma, 2009, p. 7).

With the exception of the World Systems Theory which stressed that there existed a substantial "semi-periphery" in the contemporary world system, radical dependency approaches too reduced the development reality into binary dichotomies such as “core and periphery”, "rich and poor”, “developed and underdeveloped” and so on (Desai \& Potter, 2002), rarely acknowledging the unending continuum of alternative 
economic conceptions. Consequently, two broad categories of development philosophies (growth-orientation and people-centeredness) gained currency (Cheru, 2002; Davids, 2005; Monaheng, 2000; Ros, 2007; Todaro, 1997). Notwithstanding structuralism radical dependency antithesis, growth-oriented neoclassical approaches attained hegemony whilst people-centeredness became a mere political stunt and rhetoric (Cheru, 2002; Desai \& Potter, 2002; Ilorah, 2008; Todaro, 1997). A brief review of the two categories of development philosophies should suffice.

\section{Macro-scale Economic Growth Versus Micro-scale Human Development}

Growth-orientation holds economic growth as the primary goal of development whose success is measured through aggregates such as GDP, largely operational at the macro-scale. Reliance on this approach has commonly resulted in positive economic growth rates amidst persistent poverty and stark inequalities for developing economies (Tsheola, 2002c). Its proponents argue that redistributive strategies are generally anti-growth, and the inequalities described through the Kuznets Curve are to be tolerated at the initial stages (Adams, 2001; Desai \& Potter, 2002; Monaheng, 2000; Munslow \& FitzGerald, 1997; Todaro, 1997). Macro-scale drives towards "high economic growth paths" and quantitative outputs are preferred at the expense of micro-scale qualitative human development, under the presumption that trickle-down economics would avail income and jobs for the poor. But evidence suggests that this approach is inherently discriminatory against poor people, especially in developing economies where poverty is deep and widespread.

People-centeredness places focus at the micro-scale of societal contact with policy to promote people's involvement for empowerment and qualitative human development (Monaheng, 2000). This development philosophy exults the adage that "development is about people”, who should be both the vehicle and beneficiaries of their own development (Davids, 2005; Theron, 2005a), and its practice entails adoption of instruments for the devolution of power, control, ownership and determination of direction of the process of development to the micro-scale (Cook, 1997). Giving pragmatic effect to the principles of people-centeredness, under developing economies' conditions of poverty and inequalities, requires the recognition and treatment of familial assets they control within the hegemonic economics of capital accumulation.

A variant of the people-centeredness philosophy, community development, provides for a micro-scale, poverty-oriented and multifaceted strategic front, founded on the notion of devolution of power and control. That is, empowerment entails accrual of subjective power, competence and objective power to ordinary people, as essential building blocks for becoming primary actors in the development process. Empowerment, participation, capacity, performance, sustainability, ownership and control of productive assets and resources, exchange of usable knowledge and information, and motivation, are inseparable complementary foundational bases for people-centeredness whereby contact with development policy incrementally engenders conditions of "being developed”, encapsulated in the three core values of improved standards of living, high self-esteem and total freedom of choice (Monaheng, 2000; Theron, 2005a). Under the hegemonic macroeconomics, poor people are excluded from participation in the economics of capital accumulation; and, a fundamental transformation of the determination of the asset base treatable as productive and investment capital in order to accommodate those managed by poor people in developing economies is necessary. But giving pragmatic effect to the principles of people-centeredness has remained elusive, largely because the requirement for devolution of power and control 
of productive and investment capital has commonly been overshadowed by short-term quick-fixes such as social grants. Under neoliberal macroeconomics, the rules for capital accumulation are already predetermined and discriminatory against poor people's asset base. But broad-based participation, empowerment and human development would take place if the bottom-half of the population is appropriately capitalised or recapitalised, and developing economies' transformative agendas cannot afford to ignore the foundational norms of economics, as "the logic of a system".

\section{Foundational Norms of Economics as the Logic of a System}

The primary assumption underlying growth-orientation is that income and employment are fundamental to development because they can create the capacity for people to achieve a better life (Cheru, 2002; Ros, 2007; Todaro, 1997). High growth rates and wealth generation would presumably trickle-down to the poorest sectors of the population through income and employment (Monaheng, 2000; Davis, 2005; Theron, 2005a, 2005b; Todaro, 1997). Ros (2007) dismisses this proposition because neoliberal macroeconomics is structured with strong "centrifugal” and weak "centripetal" forces at the extremes of the income distribution spectrum. Centrifugal forces deepen the diversity of shares of national income between the poor and the rich, and these forces are immanent in developing economies where inequalities are stark (Amin, 2001; Bayart, 2000; Cheru, 2002; Ros, 2007; Todaro, 1997). The strength of these “centrifugal” forces is sustained by the circumvention of poor people's asset base and exclusion from treatment as productive and investment capital. Conversely, the weak "centripetal" forces are presumed to promote convergence of shares of national income between different sections of the population (Cheru, 2002; Ros, 2007; Todaro, 1997). Post-apartheid South Africa's stark inequalities should suggest that the "centrifugal”, rather than "centripetal” forces are preeminent. Economic growth by itself does not instigate automatic trickle-down of income and employment to poor people. This article shows that South Africa's positive economic growth was not accompanied by centripetal shifts in national income and jobs.

A second foundational assumption of neoliberal economics is that people participate beneficially in the accumulation process by treating their assets as productive and investment capital (Todaro, 1997). But poor people's "asset base" is excluded from the neoliberal economics of capital accumulation. Developing economies have attempted to transfer and replicate the modern mainstream "asset base" into traditional rural communities to no avail; also, poor people's familial asset base is undermined as unproductive and non-investible under the neoliberal macroeconomics. Developing economies' transformative agenda should therefore seek to capitalise or recapitalise poor people, most preferably through their familial asset base.

The third norm of neoliberal macroeconomics conceives economic growth as a function of the increase in efficiency and productivity, which are dependent upon a range of factors, including human capital, infrastructure investment, trade reform and contestable market established through competition policy (Cassim, 2006; Ilorah, 2008; Todaro, 1997). Indeed, GEAR's economics is heavily depended on total factor productivity (TFP) growth, wherein improvements involve shedding jobs and rendering the country's abundant productivity resource, labour, a marginal contributor to growth (Cassim, 2006). Under such pursuits of efficiency and productivity, economic growth trickle-down presumption becomes unrealistic.

Successful incubation of people empowerment in developing economies entails fundamental economic and 
socio-spatial transformation and conception of economics in accordance with the societal knowledge and context (Nabudere, 2006). Whereas poor people's traditional mud and brick houses, shacks and donkey carts cannot be rented or sold, their lands are degraded and productively marginal. Thus, interventions that do not seek to fundamentally transform the hegemonic macroeconomics' norms would not create the opportunity for poor people to share in the benefits of growth. Whereas vested interests would dispel attempts to fundamentally transform the system for inclusion of poor people's “asset base”, calls for their (re)capitalisation would be dismissed as retrogressive, because social perceptions are frozen at levels predetermined by the rules of the hegemonic economics of capital accumulation.

In South Africa, people-centeredness and devolution of power for the control of development have not progressed beyond the RDP rhetoric; and, the majority of poor people manage assets that are not treatable as productive or investment capital. Whereas GEAR failed to engender broad-based participation, AsgiSA's hope of shared growth remains unrealistic because it too does not seek to transform the economics for (re)capitalisation of the bottom-half of the population for participation in capital accumulation.

\section{South Africa's Macroeconomic Frameworks}

A brief analysis of key features of post-apartheid development policy frameworks will demonstrate that GEAR became hegemonic, establishing a development landscape devoid of people empowerment. In response to the massive racially-inspired poverty and inequality, the RDP conceived economics as a servant for human development (Padayachee, 2006). It set a three-pronged vision wherein reconstruction and development were designed to induce socio-spatial transformation without constraining the potential for the economics of capital accumulation, whilst ensuring environmental sustainability (Tsheola, 2002a). Perhaps the RDP's avoidance of simplistic binary conceptions of economics was its downfall because the simultaneous drives for growth, redistribution and sustainability was too ambitious for a developing economy. By mid-1996, GEAR macro-policy superseded the RDP, becoming hegemonic (Padayachee, 2006; Tsheola, 2002a). Far from the RDP goals, GEAR conceived economics as “the logic of a system”, rather than a "servant of humanity’s development”, unambiguously proposing "a pro-growth strategy entailing fiscal prudence, trade reform and public-sector reform with the aim of creating a more market-friendly, efficient economy” (Cassim, 2006, p. 56), wherein business would presumably thrive through global competition whilst poor people benefit from trickle-down economics of jobs, income and economies of scale (Padayachee, 2006; Legum 2002). Contrary to the RDP's redistributive propensities, GEAR was perhaps an embodiment of the TINA paralysis wherein pertinent questions about the spatial fix, geographical unevenness, profound contradictions, injustices and material inequality immanent in free market capitalism were suppressed. Reverence of GEAR's political-economy found expression in questions of how its growth could be shared.

Setting out to achieve $6 \%$ annual growth rate and to generate 400,000 jobs per annum by 2000, GEAR conceived specific growth-oriented strategies and programmes in Trade and Investment, Industrial Growth, Export Regimes, Motor Industry Development Programme (MIDP), and so on. In external relations, it enforced trade liberalisation, locking South Africa into a commitment to the World Trade Organisation (WTO) tariff reduction schedule from an average of $11.7 \%$ to below 5\% between 1994 and 2004 (Cassim, 2006). The Industrial Policy Reform gradually eliminated the so-called price-distorting measures such as export subsidies, 
except in the automotive and clothing and textile industries (Cassim, 2006). Whereas GEAR's incremental positive economic growth never reached 6\% per annum, employment generation fell below the annual target by about 19\% over the past five years to 2007, whilst unemployment rate remained above 25\% per annum until 2006 (RSA, 2007). Poor people largely remained outside the economics of trickle-down and capital accumulation.

AsgiSA was adopted at the beginning of 2006 in the hope of ensuring that GEAR's positive economic growth could be "shared" by all South Africans (RSA, 2006). It provides "a set of interventions to promote and create conditions for accelerated and shared growth and development” in six areas: building infrastructure to grow the capacity of the economy; boosting sectors of the economy with special potential for faster growth; developing the skills needed by the economy; addressing inequalities that marginalise the poor in the "Second Economy"; continuing with the policies that have created a good climate for growth; and, making government more effective and efficient (RSA, 2006, p. 3). These provisions are not fundamentally new; importantly, they do not seek to transform the macroeconomic norms for (re)capitalisation of the bottom-half of the society, whose asset base is circumvented by the economics of capital accumulation. Under AsgiSA, resourceful assets treatable as capital, continue to be predetermined in ways that discriminate against poor people's asset base. Rather than transforming the political-economy landscape, AsgiSA merely sets out to use the previously existing infrastructure investment instruments such as the Municipal Infrastructure Grant, Expanded Public Works Programme (EPWP) and so on, hoping to improve service delivery in the "Second Economy" (RSA, 2006). The use of funding policy instruments such as the Integrated Sustainable Rural Development (ISRD), the EPWP, the Joint Initiative on Priority Skills Acquisition (JIPSA) and the Integrated Development Plans (IDPs), devoid of transformation of the basic norms of neoliberal macroeconomics for recognition and treatment of the asset base of the poor as productive and investment capital remains unhelpful. Whereas the provision of economic and social overhead capital is crucial, its delivery cannot automatically (re)capitalise the bottom-half of the society.

The philosophical principles underwriting AsgiSA remain income and employment generation, and the quantitative development outcomes measureable at the macro-scale (Boraht, 2007; Woodriffe, 2007). Its Programme of Action and “interventions in the 'First Economy' to speed up progress towards faster growth and development of at least $6 \%$ a year", and to "sustain and improve... social development programmes aimed at providing support to those most exposed to the threat of abject poverty” (RSA, 2006, p. 2) would most likely remain cosmetic. Like GEAR, AsgiSA seeks to achieve quantitative growth-oriented objectives of $4.5 \%$ annual growth rate over the period 2006-2009 and 6\% between 2010-2014 (RSA, 2006; Woodriffe, 2007). Whilst these targets are realistic, the assumption that "high" growth rates and wealth generation would by themselves trickle-down to the poorest through income and employment is questionable. According to Woodriffe (2007, p. 37), the word “shared” in AsgiSA means “bringing as many South Africans as possible into the 'First Economy' through creating employment or income and wealth opportunities so that all may benefit from future economic growth”. But availing the poor to the capitalist logic as labourers, rather than as managers of productive and investment capital is not congruent with empowerment.

Growth-orientation amidst widespread inequalities and severe poverty would potentially entrench deleterious social welfare dependency, and AsgiSA does not provide for recognition and treatment of the poor's asset base as productive and investment capital for independent involvement in the economics of capital accumulation. Poor people's participation in the "First Economy" should go beyond trickle-down of jobs and 
income. People-centeredness and human development remain delusional for post-apartheid South Africa. The attainment of positive economic growth amidst the lack of people empowerment, decrease in poverty rate and increasing dependence on social welfare defines a Janus-faced development associated with GEAR, which AsgiSA would fail to resolve.

\section{Post-apartheid South Africa's Janus-Faced Development}

Legum (2002, pp. vi-vii) argues that South Africa's unquestioning dependence on neoliberal macroeconomics led to "appalling poverty in the midst of unbearable wealth and potential plenty for everyone". The Minister of Trade and Industry (DTI) accepted that adherence to the Thatcherite economics caused Janus-faced development (Creamer, 2007) of positive and increasing economic growth rates, increasing rates in the standards of living and decreasing poverty rate amidst persistent inequalities and increasing dependence on social welfare. Apparently, increases in the rate of average standard of living from 1.3\% to 3.03\% between 1994 and 2007 are accounted for by the decrease in population growth rate from $1.9 \%$ to $0.97 \%$ over the same period (see Figure 1). Whilst annual GDP growth rates increased from 3.2\% to 5.0\% and 4.02\% in 1994, 2006 and 2007, respectively, and poverty rate, calculated at the R 3,000 per annum poverty line, declined from $50 \%$ to $43.2 \%$, inequalities remained persistently high with average annual Gini-coefficient above 0.675 (RSA, 2007). Importantly, share of national income by the poorest and richest sections of the population remained starkly divergent over the same period.

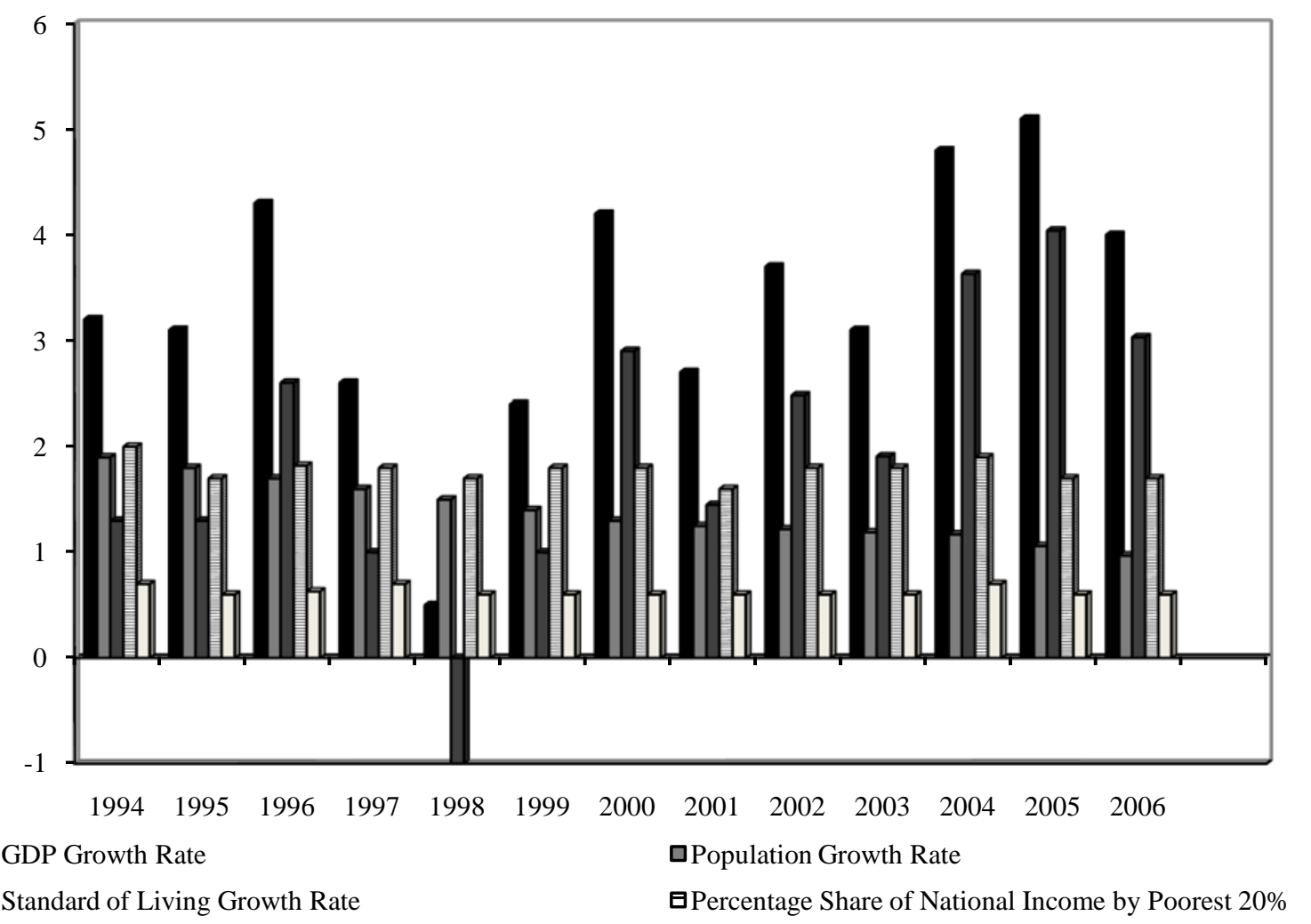

$\square$ Percentage Share of National Income by the Poorest $10 \%$

Figure 1. Annual growth rates in GDP, population, average standard of living and share of national income by the poorest sectors of the population, 1994-2006. 
The positive economic growth together with persistent inequalities and concentration of national income in the hands of a minority, discounts imputations that the general standard of living might have improved in absolute terms. As the share of total income accruing to the poorest $20 \%$ of the population decreased from $2.0 \%$ to $1.7 \%$ between 1994 and 2006 that for the richest 20\% increased, though marginally, from 72.0\% to 72.5\% (RSA, 2007). Accompanying the stark inequalities was a decline in poverty rate (see Figure 2), apparently accounted for by the increased number of beneficiaries of social welfare from 2.5 to 12 million between 1999 and 2007 (RSA, 2007). Notwithstanding the dangers of societal dependency syndrome, AsgiSA draws inspiration from the speedy expansion of social services and the substantial increase in the number of beneficiaries of social grants (RSA, 2006).

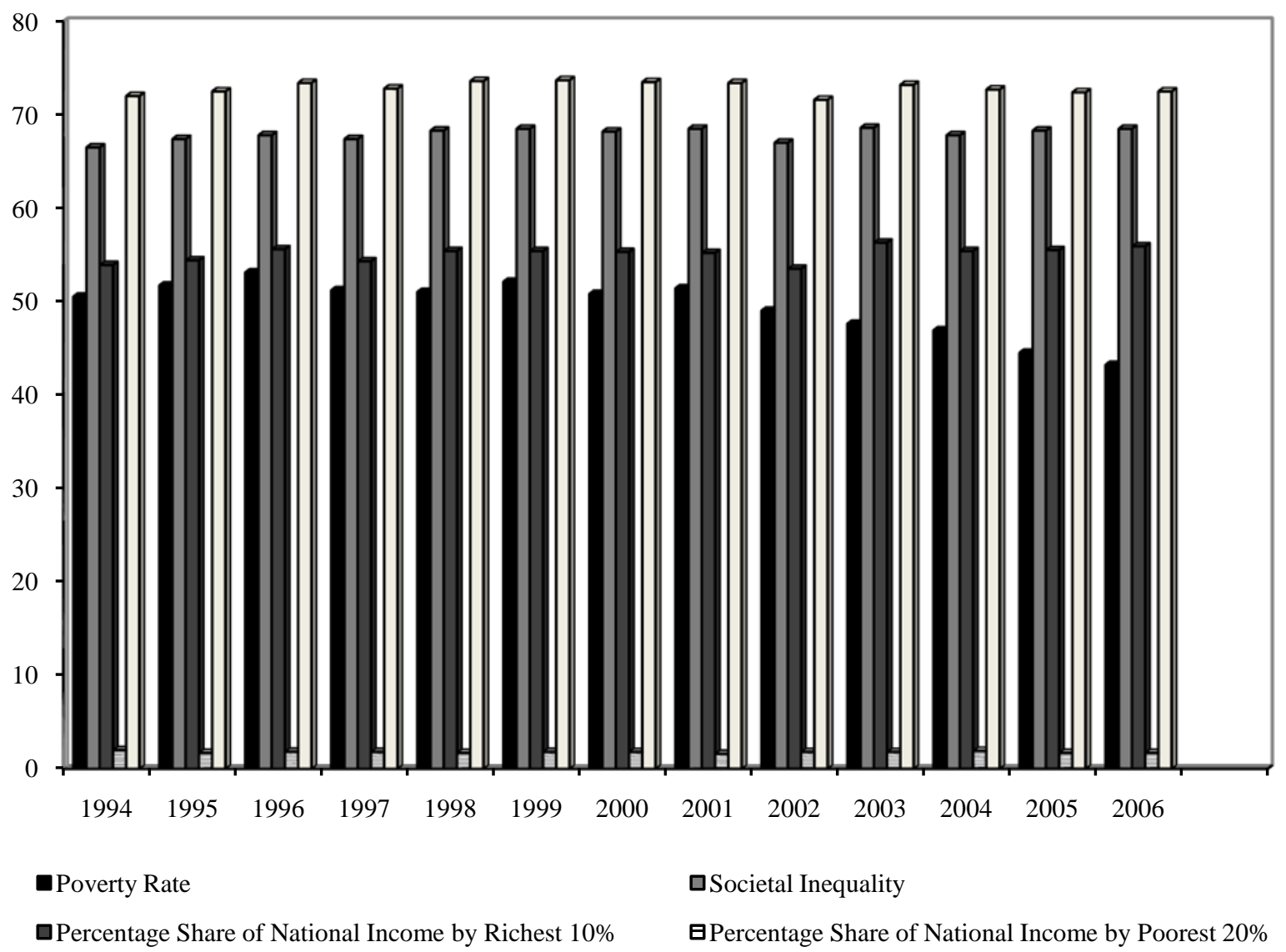

口Percentage Share of National Income by Richest 20\%

Figure 2. Annual poverty rates, societal inequality and share of national income by sectors of the population, 1994-2006.

Dependence on social welfare is a far cry from the ideal of people empowerment, especially where 7 million of the beneficiaries in 2006 were children receiving Child Support Grant (see Figure 3). Evidently, the decline in poverty rate could not have been a direct outcome of the growth-orientation, trickle-down economics. Unemployment rate remained persistently high because the positive economic growth resulted from unsustainable, strong consumer demand financed by borrowing (RSA, 2006). Under such circumstances, "the free market ideology' rendered 'growth and development hostage to finance... at the expense of economic 
rationality” (Adedeji, 2009, p. 4). Positive economic growth occurred simultaneously as imports increased, creating a resources gap in foreign exchange, notwithstanding the increase in the value of exports as percentage of GDP from 23.3\% to 30.8\% between 1994 and 2006 (RSA, 2007).

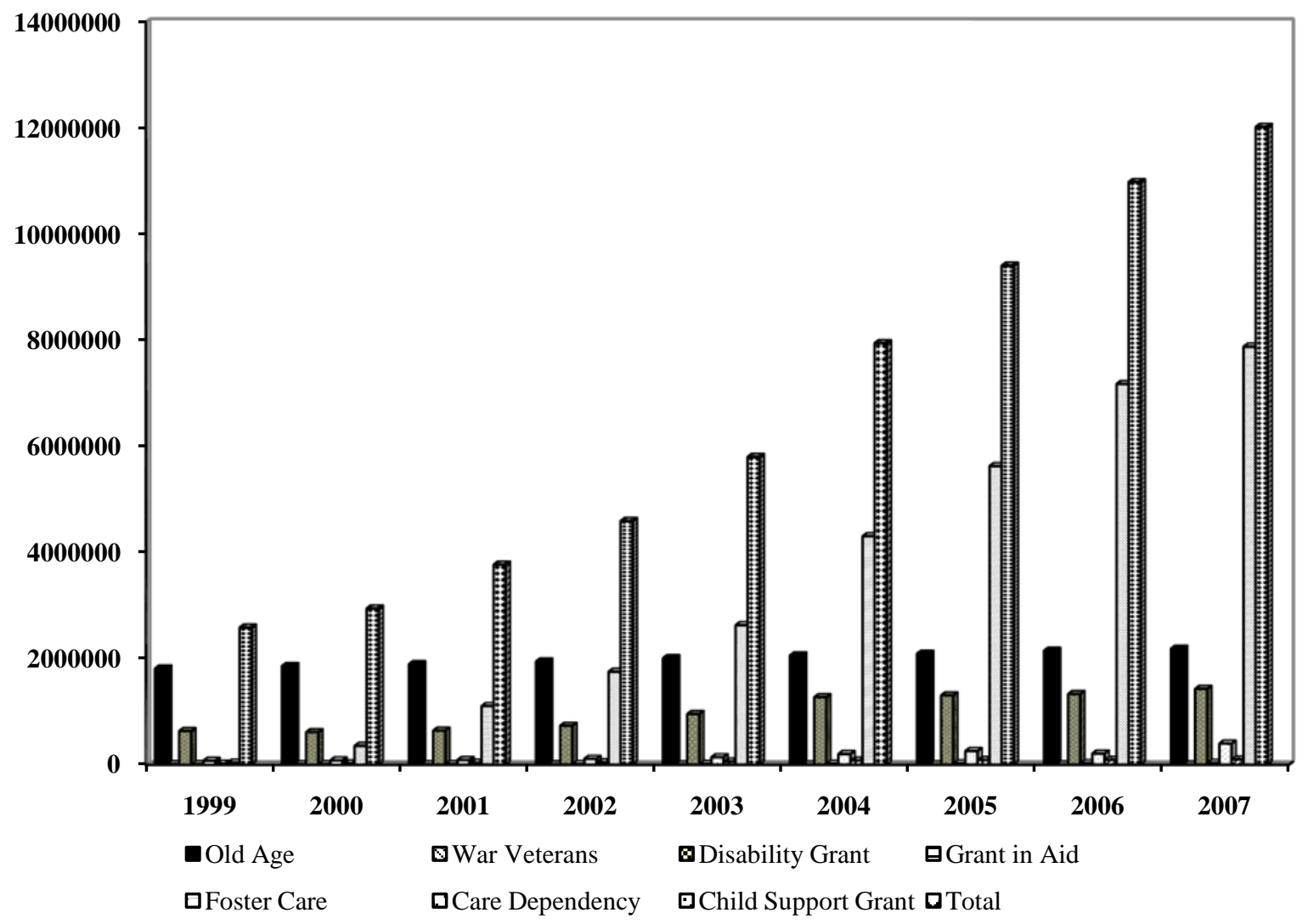

Figure 3. Dependence on social grants, 1999-2007.

But social expenditure was kept under control and the expansion of social welfare was not necessarily financed through increased government debt. The latter trended downwards as a percentage of GDP from 43.5\% to 33.5\% between 1994 and 2006, despite attaining a high of 49.9\% in 1999 (RSA, 2007). As poverty rate declined, government budget deficit before borrowing as percentage of GDP also declined consistently from $-9.1 \%$ to $-0.3 \%$ between 1994 and 2006 (RSA, 2007). The upward trend in the value of exports as percentage of GDP appears to have made a negligible contribution to the positive economic growth because whilst the value of imports increased, the expected FDI flows did not materialise. FDI flows remained unreliable and a significant amount of South African capital relocated offshore in 2006 (see Figure 4).

Mergers and acquisitions transactions, associated with jobs shedding and a highly selective Black Economic Empowerment (BEE) for the so-called "empowerment A-list”, dominated inflows of foreign capital (Cassim, 2006). GEAR's pursuit of greater efficiency and investment-friendly macro-policy failed to enhance FDI and exportation (Cassim, 2006). Whereas the rate of average standard of living increased, the Living Standard Measure (LSM) shows that the majority of South Africans lacked access to the wealth generated through GEAR (see Figure 5). 


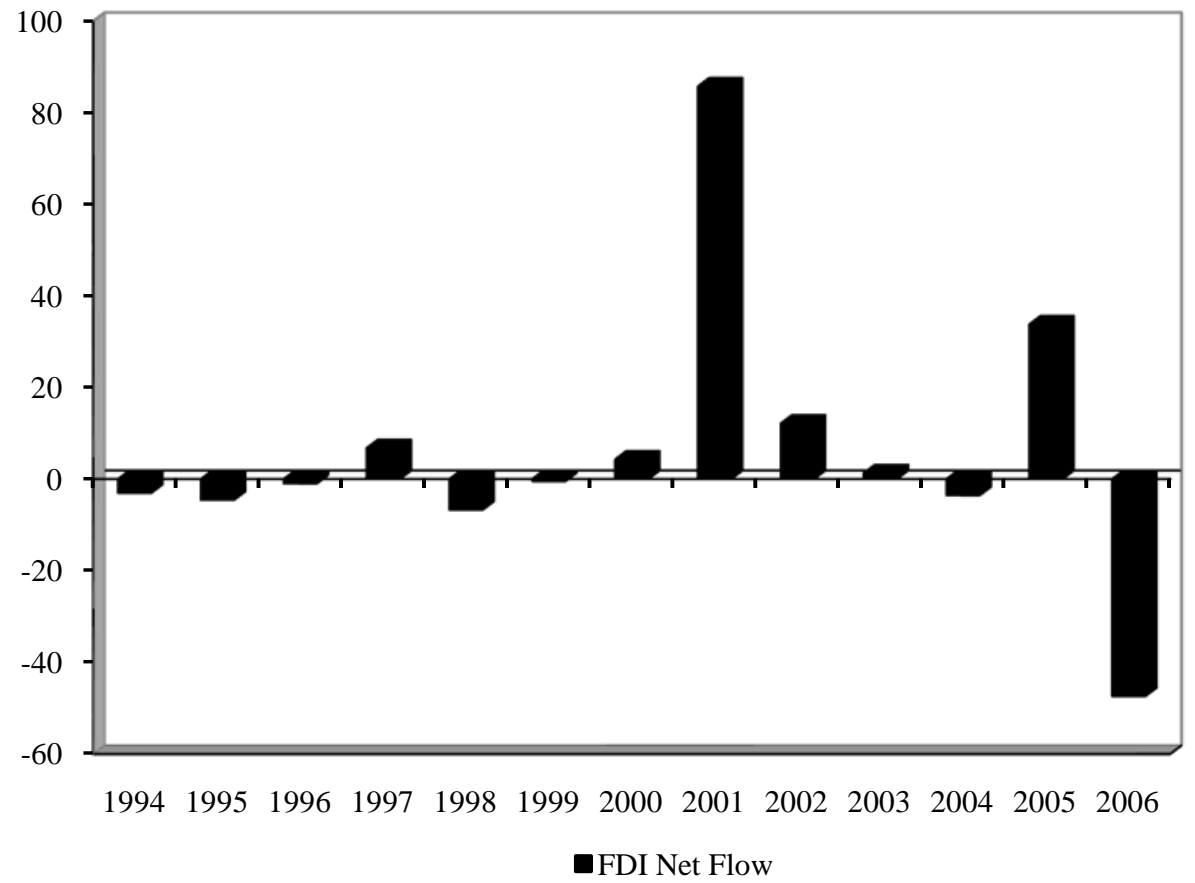

Figure 4. FDI net flow (R billion), 1994-2006.

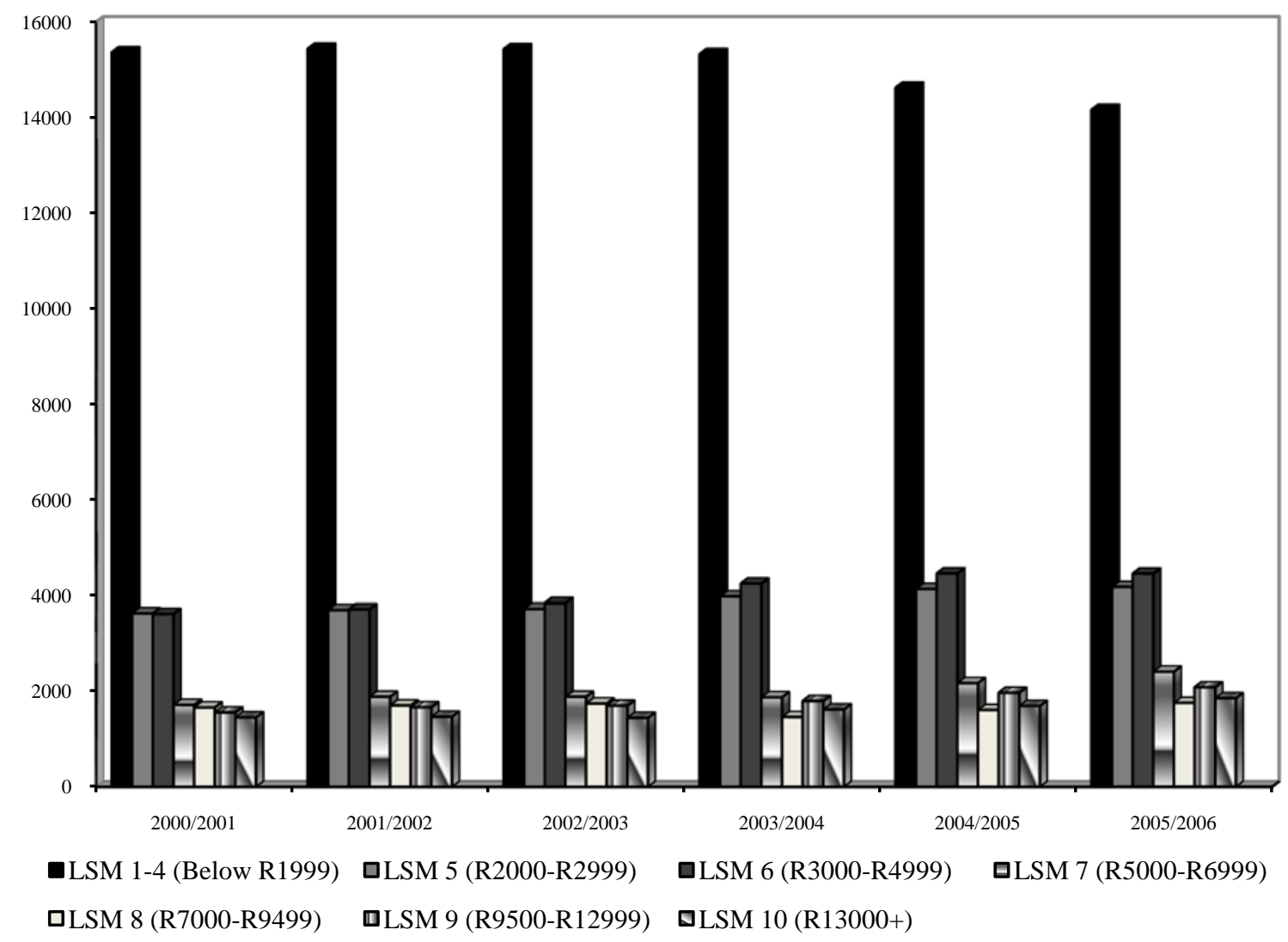

Figure 5. Population (thousands) by living standard measure (imputed monthly average income), 2000-2007. 
Between 2000 and 2006, an overwhelming majority received monthly incomes of less than R 3,000, locating within LSM 1-5. This section of the population is the poorest, managing marginal assets that are generally excluded from the economics of capital accumulation. An erroneous impression could be created that the apartheid land ownership status quo was transformed as the number of hectors in the hands of poor people increased from 15,395 to 1,486,399 between 1996 and 2006 (RSA, 2007). A significant proportion of this land is productively marginal and extraordinarily difficult to exploit as assets for capital accumulation. The new beneficiaries of land reform were exposed to the harsh effects of neo-liberalism as apartheid's high protective tariffs were incrementally eroded. In 2006, over 72 such farmlands in Limpopo Province were listed for deregistration because the beneficiaries failed to treat them as productive and investment capital.

Accumulation of land assets by the formerly disadvantaged people did not enable them to participate in the economics of capital accumulation. The decline in Human Development Index (HDI) from 0.73 to 0.67 and life expectancy from 54.9 to 50.7 years between 1995 and 2006 suggests general deterioration in human development (RSA, 2007; UNDP, 2004). These trends held simultaneously as the economy grew, social welfare expanded and unemployment rate declining marginally (see Figure 6). The negligible share of income by the poorest $20 \%$ of the population suggests that trickle-down economics did not happen and the economy's absorption capacity remained weak. Average dependency ratio stood around 7 dependents per working adult, reaching 19 in cases such as Sekhukhune District Municipality. But official and unofficial unemployment rates decreased from 29.4\% to $25.5 \%$ and $40.6 \%$ to $37.3 \%$, respectively, over the period of five years to September 2006 (RSA, 2007).

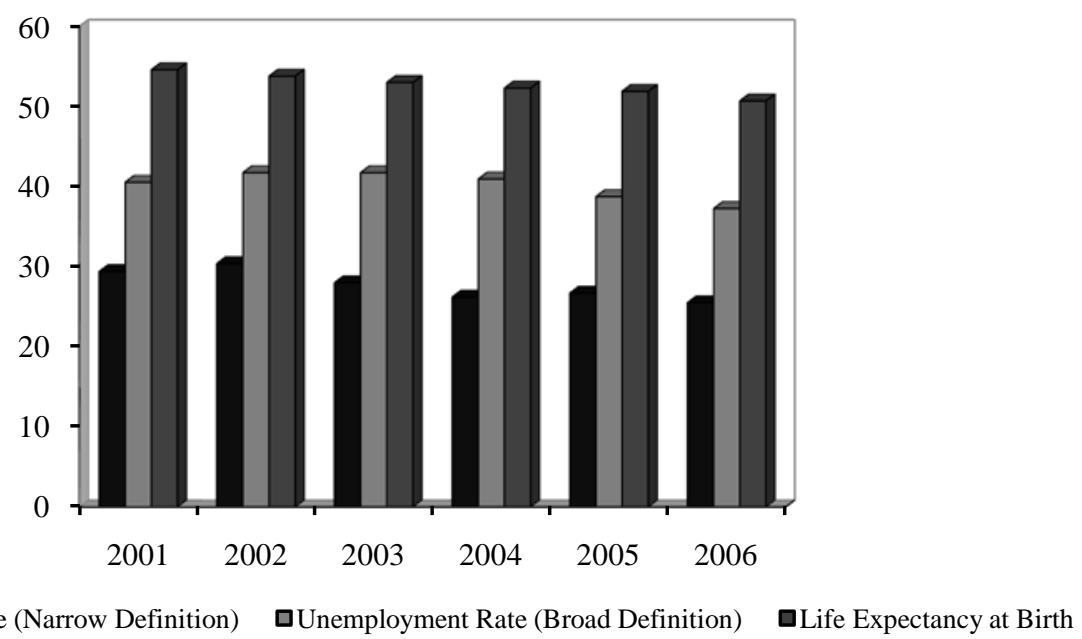

Figure 6. Trends in unemployment and life expectancy, 2001-2006.

This article infers that GEAR's growth-orientation is devoid of people empowerment and human development. The trickle-down assumption did not hold because the growth accounting frameworks show that GEAR's growth was founded on the TFP wherein an increase in efficiency and output "resulted in a less than proportionate increase in employment" (Cassim, 2006, p.56). The article asserts that rather than reliance on trickle-down economics, poor people should be empowered for participation in capital accumulation through (re)capitalisation. Most poor South Africans own land and dwellings within rural tribal settlements where it is almost impossible to treat them as productive and investment capital. The most familial assets for the majority of rural South Africans are a brick structure on separate stand and traditional mud house (see Figure 7). 


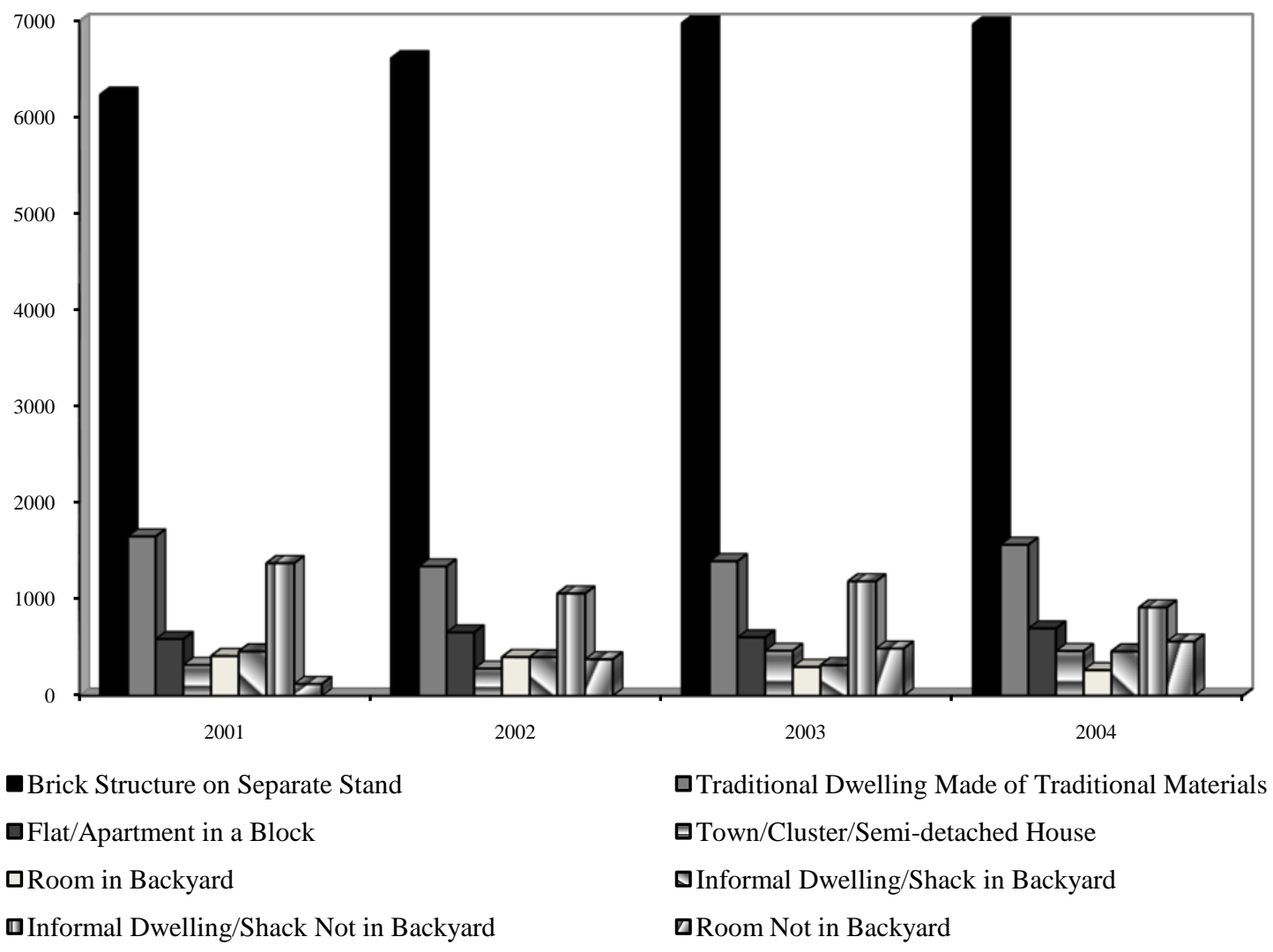

Figure 7. Assets of the poor per thousands of households by type of dwelling owned, 2001-2004.

This familial asset base of the poor is excluded from the process of capital accumulation because it cannot be rented or used as investment. This article asserts that transformation and support of this familial asset base of the poor for treatment as capital within the hegemonic neoliberal macroeconomics provides an inescapable key towards unlocking poor people's potential for empowerment. For this reason, the article infers that AsgiSA too would not engender people empowerment because it does not seek to enforce recognition and treatment of the poor's familial asset base as productive and investment capital on the same footing as the modern mainstream assets.

AsgiSA sets out to perpetuate GEAR norms. The former National Treasury director-general, LesetjaKganyago, confirmed that South Africa will continue to apply "economic orthodoxy" wherein development and investment are "driven by the selfish interest that is meant to drive capitalism” (Creamer, 2007, p. 9). According to May (2006, p. 148), "the assumption that the adoption of growth-friendly policies by all countries or regions results in a win-win situation” flies in the face of overwhelming evidence to the contrary. South Africa's Janus-faced development adds to the pool of evidence.

\section{Conclusion}

Notwithstanding the decline in poverty and unemployment rates, income inequalities have remained substantially high under the GEAR-driven positive economic growth. AsgiSA itself acknowledges that the 
positive economic growth attained through GEAR is unsustainable because it is largely achieved through heavy reliance on credit-financed strong consumer demand, rather than export expansion (RSA, 2006). The recent global crisis attests to the dangers inherent in financial markets that rely heavily on credit-financed strong consumer demand. GEAR too led to increased import demand, recreating the requirements for increased foreign capital inflows (RSA, 2006).

The lesson to be drawn from South Africa's Janus-faced development is that policy instruments that do not transform poor people's familial asset base for treatment as productive and investment capital do not incubate authentic people's participation and empowerment. Increasing the number of people who "share" in the national growth through the expansion of social welfare grants does not devolve power, control, ownership and determination of direction of development to the micro-scale. The prospects of achieving such devolution of control, where poverty is deep and widespread, are embedded with the treatment of poor people's familial asset base as productive and investment capital. The modus operandi for such a treatment of poor people's asset base on the same footing as the modern mainstream assets should necessarily be paradoxical and contradictory. The Pareto Optimum Theorem of the efficient market entails making many people worse-off in order to make a few individuals better-off. Also, societal perceptions continue to be frozen at a level where assets managed by the majority of the poor are considered to be economically unproductive and wasteful of investment. In the “TINA-styled” economics, creativity about treatment of poor people’s asset base remains truncated even in countries where they constitute a potentially resourceful majority. AsgiSA, just like GEAR, does not address this critical challenge.

This article concludes that post-apartheid development practice, underwritten by GEAR macroeconomics, is largely responsible for the lack of people empowerment and human development as well as the perpetuation of exclusion of the poor's familial assets from treatment as productive and investment capital. Whether or not neoliberal macroeconomics can be transformed and reconstituted to embrace assets of the poor in the process of capital accumulation is a conceptual moot point; but the circumvention of poor people's familial asset base will most certainly perpetuate severe and widespread poverty, stark inequalities and trends of positive economic growth devoid of human development or empowerment.

\section{References}

Adams, W. M. (2001). Green development: Environment and sustainability in the third world (2nd ed.). London: Routledge.

Adedeji, A. (2009). Africa and the crisis of global financial governance. South African Journal of Social and Economic Policy, 33(1st Quarter), 4-5.

African National Congress. (ANC). (1994). The reconstruction and development programme: A policy framework. Johannesburg: Umanyano.

Amin, S. (2001). Africa: Living on the fringes? Africa Insight, 31(2), 3-7.

Bayart, J. F. (2000). Africa in the world: A history of extraversion. African Affairs, 99(395), 217-267.

Bhorat, H. (2007). ASGISA and growth. South African Journal of Social and Economic Policy, 25(1st Quarter), 35-36.

Cassim, R. (2006). Reflections on South Africa’s first wave of economic reforms. In V. Padayachee (Ed.), The development decade? Economic and social change in South Africa, 1994-2004 (pp. 55-85). Cape Town: HSRC.

Cheru, F. (2002). African renaissance: Roadmaps to the challenge of globalization. London: Zed Books.

Cloete, F. (2006). Public policy in more and lesser developed states. In F. Cloete, H. Wissink, \& C. de Coning (Eds.), Improving public policy: From theory to practice (2nd ed.) (pp. 83-102). Pretoria: Van Schaik. 
Cook, J. (1997). Empowering people for sustainable development. In P. Fitzgerald, A. McLennan, \& B. Munslow (Eds.), Managing sustainable development in South Africa (2nd ed.) (pp. 275-291). Cape Town: OUP.

Creamer, T. (2007, August 17-23). Speaking past one another? Engineering News, 27(31), 9.

Davids, I. (2005). Poverty in South Africa: A development management perspective. In I. Davids, F. Theron, \& K. J. Mapunye (Eds.), Participatory development in South Africa: A development management perspective (pp. 37-47). Pretoria: Van Schaik.

De Coning, C. (2006). The nature and role of public policy. In F. Cloete, H. Wissink, \& C. de Coning (Eds.), Improving public policy: From theory to practice (2nd ed.) (pp. 3-26). Pretoria: Van Schaik.

Desai, V., \& Potter, R. B. (Eds.). (2002). The companion to development studies. London: Arnold.

Dlamini-Zuma, N. (2009). The world at crossroads. South African Journal of Social and Economic Policy, 33(1st Quarter), 6-8.

Ilorah, R. (2008). Trade, aid and national development in Africa. Development Southern Africa, 25(1), 83-98.

Legum, M. (2002). It doesn't have to be like this! A new economy for South Africa and the world. Kenilworth: Ampersand.

May, J. (2006). Constructing the social policy agenda: conceptual debates around povertyand inequality. In V. Padayachee (Ed.), The development decade? Economic and social change in South Africa, 1994-2004 (pp. 143-159). Cape Town: HSRC.

Monaheng, T. (2000). Community development and empowerment. In F. de Beer, \& H. Swanepoel (Eds.), Introduction to development studies (2nd ed.) (pp. 124-137). Cape Town: OUP.

Munslow, B., \& Fitzgerald, P. (1997). Search for a development strategy: The RDP and beyond. In P. Fitzgerald, A. McLennan, \& B. Munslow (Eds.), Managing sustainable development in South Africa (2nd ed.) (pp. 41-61). Cape Town: OUP.

Munslow, B., Fitzgerald, P., \& McLennan, A. (1997). Sustainable development: Visions and realities. In P. Fitzgerald, A. McLennan, \& B. Munslow (Eds.), Managing sustainable development in South Africa (2nd ed.) (pp. 3-37). Cape Town: OUP.

Nabudere, D. W. (2006). Development theories, knowledge production and emancipator practice. In V. Padayachee (Ed.), The development decade? Economic and social change in South Africa, 1994-2004 (pp. 33-52). Cape Town: HSRC.

Padayachee, V. (2006). Development discourses in post-apartheid South Africa. In V. Padayachee (Ed.), The development decade? Economic and social change in South Africa, 1994-2004 (pp. 1-10). Cape Town: HSRC.

Republic of South Africa (RSA). (2006). Accelerated and shared growth initiative-South Africa (ASGISA). Pretoria: Government Printers.

Republic of South Africa (RSA). (2007). Development indicators mid-term review. Pretoria: Government Printers.

Ros, J. (2007). Global trends in income inequality and social progress in the midst of slow growth in Latin America: The democratic dividend or the demographic transition? Paper presented to the HSRC Seminar on "Employment, Growth and Development Initiative”, 23 May, Pretoria, South Africa.

Theron, F. (2005a). Trends in micro-level development. In I. Davids, F. Theron, \& J. Mapunye (Eds.), Participatory development in South Africa: A development management perspective (pp. 104-110). Pretoria: Van Schaik.

Theron, F. (2005b). Integrated development planning as a micro-level development strategy. In I. Davids, F. Theron, \& K. J. Mapunye (Eds.), Participatory development in South Africa: A development management perspective (pp. 133-148). Pretoria: Van Schaik.

Todaro, M. P. (1997). Economic development. London: Longman.

Tsheola, J. (2002a). Basic needs in the Northern Province and South Africa's globalisation agenda. African Development Review, 14(1), 48-74.

Tsheola, J. (2002b). South Africa's form of globalization: A continental posture paradox for insertion and dependence. Political Geography, 21, 789-811.

Tsheola, J. (2002c). South Africa in GEAR: “A better life for all” or a zero-sum game of globalization? Geo Journal, 57, 15-28.

Tsheola, J. (2003). The political-economy of structural adjustment and globalisation: South Africa within (Southern) Africa (Ph.D. Thesis, University of the North, South Africa).

United Nations Development Programme (UNDP). (2004). South Africa Human Development Report, 2003. Oxford: OUP.

Woodriffe, R. (2007). Accelerated shared growth initiative for South Africa (AsgiSA): Will growth be shared? South African Journal of Social and Economic Policy, 25(1st Quarter), 37. 